\title{
Reference values for nutritional diagnosis of 'Gigante' cactus pear by DRIS and BIK methods
}

\section{Valores de referência para diagnose nutricional de palma forrageira 'Gigante' pelos métodos DRIS e IBK}

\author{
Marcelo Batista Teixeira ${ }^{1 *} \odot$, Sérgio Luiz Rodrigues Donato ${ }^{2}$, \\ João Abel da Silva²๑, Paulo Emílio Rodrigues Donato
}

'Instituto Federal da Bahia/IFBA, Seabra, BA, Brasil

2Instituto Federal Baiano/IFBaiano, Guanambi, BA, Brasil

${ }^{*}$ Corresponding author: marcelobtea@gmail.com

Received in May 21, 2021 and approved in September 17, 2021

\begin{abstract}
The equilibrium and nutritional balance of plants are known to be of utmost importance to evaluate their yield potential and to comprehend the dynamics of nutrients in the soil-plant system. Hence, the present study determined the reference values for evaluating the nutritional status of 'Gigante' cactus pear cultivated with organic fertilization in semiarid conditions by Diagnosis and Recommendation Integrated System (DRIS) and Balanced Indexes of Kenworthy (BIK) methods. The cladodes nutrients contents and dry matter yield of 72 plots were employed. The database was classified into a high-yield and low-yield population, above and below $19.93 \mathrm{Mg} \mathrm{ha}^{-1} \mathrm{cycle}^{-1}$, respectively. The five ranges of nutrient contents in cladodes were defined based on the standard deviation range(s) of the DRIS indexes of the highyield population. Furthermore, the fixed BIK values made it possible to ascertain the lower and the upper limit of the reference values of nutrient contents in the cladodes. The reference values for all nutrients determined by the DRIS and BIK methods varied from each other and those reported in the literature. These methods were efficient in identifying the limiting nutrients for 'Gigante' cactus pear, with differences in the hierarchical order of limitation, due to lack or excess, and nutrients not limiting to productivity.
\end{abstract}

Index terms: Opuntia; optimal range; nutrient dynamic.

\section{RESUMO}

O equilíbrio e o balanço nutricional das plantas são de extrema importância para avaliar seu potencial produtivo e para compreender a dinâmica dos nutrientes no sistema solo-planta. Assim, objetivou-se determinar valores de referência para diagnose nutricional de palma forrageira 'Gigante' cultivada com adubação orgânica em condições semiáridas pelos métodos Sistema Integrado de Diagnose e Recomendação (DRIS) e Índices Balanceados de Kenworthy (IBK). Utilizaram-se teores de nutrientes dos cladódios e produtividades de matéria seca de 72 parcelas. O banco de dados foi separado em população de alta e de baixa produtividade, acima e abaixo de 19,93 $\mathrm{Mg} \mathrm{ha}^{-1} \mathrm{ciclo}^{-1}$, respectivamente. As cinco faixas dos teores de nutrientes nos cladódios foram definidas de acordo com a(s) faixa(s) de desvio padrão dos índices DRIS da subpopulação de alta produtividade. Por sua vez, com valores fixos do IBK, foi possível determinar o limite inferior e o limite superior dos valores de referência dos teores de nutrientes nos cladódios. Os valores de referência gerados para todos os nutrientes pelos métodos DRIS e IBK diferem entre si e da literatura. Esses métodos são eficientes na identificação dos nutrientes limitantes para palma forrageira 'Gigante', havendo diferenças na ordem hierárquica da limitação, por falta ou por excesso, e dos nutrientes não limitantes à produtividade.

Termos para indexação: Opuntia; teores ótimos; dinâmica dos nutrientes.

\section{INTRODUCTION}

Adaptation of the cactus pear (Opuntia ficusindica Mill.) crop to the hostile conditions of the semiarid area is attributed to its morphological and physiological characteristics that confer tolerance to long periods of drought and provide high water use efficiency (Donato et al., 2014a). The yield of this crop in Brazil accounts for
2.87 million tons, and Bahia is responsible for $45 \%$ of this production (Instituto Brasileiro de Geografia e Estatística - IBGE, 2017). Owing to its high dry matter production per unit area, high content of non-fibrous carbohydrates, good acceptability, digestibility, and good energy value, the crop provides a viable solution for feeding herds during dry periods (Almeida, 2012). 
The significance of equilibrium and nutritional balance of plants in estimating their yield potential is wellknown (Serra et al., 2010). Tissue diagnosis, reflecting the dynamics of nutrients in the soil-plant system, is employed as a complement to soil chemical analysis and visual diagnosis. As a holistic approach to elucidate the nutritional status of plants, the tissue concentration of nutrients is currently considered the most pertinent and reliable method. The dynamic nature of nutrient composition in plant tissues has been addressed by several methods (Attar; Joolka, 2015).

The Diagnosis and Recommendation Integrated System (DRIS), a method developed by Beaufils (1973), nurtures the dual rations between nutrients based on norms to explore the degree of nutrient equilibrium in the plant (Guimarães et al., 2015). On the other hand, a univariate method proposed by Kenworthy in 1961, Balanced Indexes of Kenworthy (BIK), is based on the ratio between the content of a nutrient in a sample and the critical level. This method obtains the statistical parameters such as mean and coefficient of variation from the high-yield group to be used as norms. Like DRIS, BIKs allow nutrients to be arranged in order of limitation sequences; however, to assess the nutritional status of plants, the use of specific norms for locations and cultivars in preference to universal ones is recommended (Rodrigues Filho et al., 2021).

There are limited studies that revealed the reference values for the cactus pear by the methods of nutritional diagnosis. Blanco-Macías et al. $(2009,2010)$ adopted the Compositional Nutrient Diagnosis (CND) and Boundary Line methods to elucidate the sufficiency ranges for the crop under edaphoclimatic conditions in Mexico; Teixeira et al. (2019) established the DRIS norms; the interpretive standards for nutrient content in the cladodes were determined by Alves et al. (2019a, b) with the help of the methods of Mathematical Chance (ChM) and Sufficiency Range; and Donato et al. (2017b) established the chemical attributes of the soil cultivated with 'Gigante' cactus pear by the Sufficiency Range and Critical Level methods by the reduced normal distribution (NCRIz) in semiarid conditions of Bahia.

In this context, the objective of the present study was to employ the DRIS and BIK methods to determine the reference values for nutritional diagnosis of 'Gigante' cactus pear cultivated with organic fertilization in semiarid conditions of Bahia.

\section{MATERIAL AND METHODS}

The soil used for the experiment with 'Gigante' cactus pear was originally classified as dystrophic Latossolo Vermelho-Amarelo, medium texture (Santos et al., 2018), corresponding to Oxisol (Soil Survey Staff, 2014). The area was located in the Baiano Federal Institute, Guanambi Campus, Bahia, with an average altitude of 525 $\mathrm{m}$, a latitude of $14^{\circ} 13^{\prime} 30^{\prime \prime} \mathrm{S}$, a longitude of $42^{\circ} 46^{\prime} 53^{\prime \prime} \mathrm{W}$, and the climatic conditions included annual precipitation averages of $680 \mathrm{~mm}$ and temperature $26^{\circ} \mathrm{C}$.

The present study used the basic data from Donato et al. (2014a, b, 2016, 2017a) and Barros et al. (2016). The contents of macronutrients $(\mathrm{N}, \mathrm{P}, \mathrm{K}, \mathrm{S}, \mathrm{Ca}$, and $\mathrm{Mg}$ ) and micronutrients (B, $\mathrm{Cu}, \mathrm{Fe}, \mathrm{Mn}, \mathrm{Zn}$, and $\mathrm{Na}$ ) were measured from samples collected in freshly mature cladodes. The data also included the dry matter yield (DMY) and the extraction of nutrients from 72 plots of an experiment with 'Gigante' cactus pear, whose average DMY was $19.93 \mathrm{Mg} \mathrm{ha}^{-1}$ cycle $^{-1}$.

The description of the soil attributes of the experimental area before planting the cactus pear was derived from Donato et al. (2014a, b, 2016, 2017a) and Barros et al. (2016). The sliced samples were placed for drying in a forced circulation oven at $60^{\circ} \mathrm{C}$ for $72 \mathrm{~h}$. After drying and grinding in a Willey mill with a $1 \mathrm{~mm}$ sieve, they were identified and packed in plastic pots and sent to the laboratory of the Agricultural Research Company of Minas Gerais (EPAMIG-Norte). The results of the chemical analyses of the plant tissue, along with the respective yield results, were documented and processed in a Microsoft Excel ${ }^{\circledR}$ spreadsheet.

To determine the reference values, the database was segregated into the high-yield population (HYP) and lowyield population (LYP), above and below $19.93 \mathrm{Mg} \mathrm{ha}^{-1}$ cycle $^{-1}$ of dry matter, respectively. This criterion refers to the average dry matter yield of the 72 plots. After defining the high-yield population, the Lilliefors test helped to estimate the normal distribution of yield.

Based on the high-yield population, the DRIS indexes for each nutrient were computed using the formula proposed by Beaufils (1973), being for a nutrient A:

$$
I A=\frac{\sum_{i=1}^{n} f\left(\frac{A}{B_{i}}\right)-\sum_{j=1}^{m} f\left(\frac{B_{j}}{A}\right)}{n+m}
$$

where

IA = DRIS index of the nutrient; $\sum_{i=1}^{n} f\left(\frac{A}{B_{i}}\right)=$ sum of the functions in which nutrient "A" is in the numerator;

$\sum_{j=1}^{m} f\left(\frac{B_{j}}{A}\right)=$ sum of the functions in which the nutrient " $\mathrm{A}$ " is in the denominator; 
$\mathrm{n}=$ number of times the nutrient appears in the numerator; $\mathrm{m}=$ number of times the nutrient appears in the denominator.

The value of the intermediate functions $\mathrm{f}(\mathrm{A} / \mathrm{B})$, defined as the relationship between the ration in the sample and the ration in the population, was calculated using the formula of Jones (1981):

$f(A / B)=[(A / B)-(a / b)] / s$

where

$\mathrm{A} / \mathrm{B}=$ dual ratios between the contents of nutrients $\mathrm{A}$ and $\mathrm{B}$ in the plot under diagnosis;

$a / b=$ average of dual rations between the levels of nutrients $\mathrm{A}$ and $\mathrm{B}$ in the high-yield population;

$\mathrm{s}=$ standard deviation of dual rations of nutrients $\mathrm{A}$ and $\mathrm{B}$ in high-yield population;

$\mathrm{f}(\mathrm{A} / \mathrm{B})=$ studentized range between the value of the dual ratio of nutrients $A$ and $B$ in the crop under diagnosis $(\mathrm{A} / \mathrm{B})$ and the average value of the dual ratio between nutrients $A$ and $B$ of the high-yield population $(a / b)$, expressed in units of standard deviation.

Estimation of the DRIS index of each nutrient was followed by the calculation of the nutritional balance index (NBI) and the average nutritional balance index (NBIa). The NBI was the summation of the absolute values of the indexes generated for the sample, obtained for each nutrient, whereas the NBIa was obtained by the NBI of each sample divided by the number of nutrients participating in the calculation. The interpretation of the DRIS indexes was performed by the method of the Response Potential to Fertilization (RPF), from five classes (Wadt, 2005): RPF null $(\mathrm{z})=\mid$ Inut $\mid<$ NBIa; positive or null RPF (pz) $=\mid$ Inut $\mid>$ NBIa, as long as Inut $<0$; Positive RPF $(\mathrm{p})=\mid$ Inut $\mid>$ NBIa, provided that the assessed Inut was the lowest DRIS index among the other nutrients; negative or null RPF (nz) $=\mid$ Inut $\mid>$ NBIa, as long as Inut $>0$; and negative RPF (n) $=\mid$ Inut $\mid>$ NBIa, as long as the assessed Inut was the highest DRIS index among the other nutrients. Present study also determined the frequency with which each nutrient was identified in each class.

According to Silva et al. (2005), the classes of the Response Potential to Fertilization (p, pz, z, nz, and n) were grouped in three categories of nutritional status: the positive (p) and positive or null (pz) fertilization response minimized to limiting due to lack (LF); null (z), nonlimiting (NL); and negative (n) and negative or null (nz), to limited by excess (LE).
Based on the range(s) of the standard deviation of the DRIS indexes of the high-yield population (Teixeira et al., 2019), the five ranges of nutrient contents in the cladodes were defined, where deficient nutritional status: $<-4 / 3$ s; low: $-4 / 3$ s to $-2 / 3$ s; normal: $-2 / 3$ s to $2 / 3 \mathrm{~s}$; high: $2 / 3$ s to $4 / 3 \mathrm{~s}$; and excessive: $\geq 4 / 3 \mathrm{~s}$ (Beaufils, 1973).

In turn, the standard indexes $(\mathrm{P}, \mathrm{I}$, and $\mathrm{BIK}$, expressed in percentage) were calculated from the highyield population, regardless of whether the nutrient content in the sample $\left(\mathrm{y}_{\mathrm{i}}\right)$ was higher or lower than the average content of the reference population, considered standard $(\bar{y})$, according to the method adjusted by Alvarez and Leite (1999), from Kenworthy (1973).

$$
\begin{aligned}
& P=100 y_{i} / \bar{y} \\
& I=C V\left(y_{i}-\bar{y} / \bar{y}\right) \\
& B I K=P-I
\end{aligned}
$$

where

$\mathrm{P}=$ Proportion between the nutrient content in the sample $\left(\mathrm{y}_{\mathrm{i}}\right)$ and the standard content $(\bar{y})$;

$\mathrm{I}=$ Influence of variation;

$\mathrm{CV}=\mathrm{Coefficient}$ of variation of the nutrient content in the high-yield population;

BIK $=$ Balanced Indexes of Kenworthy.

The value obtained for the Balanced Indexes of Kenworthy (BIK) was used as the basis to classify the nutrient content in the sample as follows: deficient $(<50 \%)$, below normal (50 to $83 \%$ ), normal ( 83 to $117 \%$ ), above normal (117 to $150 \%$ ), and excessive (>150\%). The five classes of relative frequency were grouped in three: the deficient and below normal classes were reduced to limiting due to lack (LF); normal, non-limiting (NL); and above normal and excessive, to excess limiting (LE), analogous to DRIS.

With fixed values of the indexes (BIK), the lower limit $\left(\mathrm{L}_{1}\right)$ and the upper limit $\left(\mathrm{L}_{\mathrm{u}}\right)$ of the reference values of nutrient contents in the cladodes were estimated using the following equation:

$$
X_{i}=\bar{x} i \frac{\left(C V_{i}-B I K\right)}{\left(C V_{i}-100\right)}
$$

where

$\mathrm{X}_{\mathrm{i}}=$ nutrient content $\mathrm{i}$ at the lower or upper limit of the class;

$\mathrm{CV}_{\mathrm{i}}=$ coefficient of variation of nutrient $\mathrm{i}$;

$\bar{x} i=$ average standard nutrient present in $\mathrm{i}$; 
$\mathrm{BIK}=$ fixed BIK values to determine the lower or upper limits of the class.

Five classes of the reference values were established. For the deficient class, $\mathrm{L}_{\mathrm{u}}: \mathrm{BIK}=50$; low, $\mathrm{L}_{1}: \mathrm{BIK}=50$ and $\mathrm{L}_{\mathrm{u}}: \mathrm{BIK}=83$; normal, $\mathrm{L}_{1}: \mathrm{BIK}=83$ and $\mathrm{L}_{\mathrm{u}}$ : $\mathrm{BIK}=117$; high, $\mathrm{L}_{1}: \mathrm{BIK}=117$ and $\mathrm{L}_{\mathrm{u}}: \mathrm{BIK}=150$; excessive, $\mathrm{L}_{\mathrm{l}}: \mathrm{BIK}$ $=150$. The optimum nutrient content was defined by the average value (100\%) balanced indexes in the normal class.

\section{RESULTS AND DISCUSSION}

A variation coefficient greater than $30 \%$ was observed for the macronutrients $\mathrm{P}$ and $\mathrm{S}$ and micronutrients, except $\mathrm{B}$, and the highest $\mathrm{CV}$ was demonstrated by the nutrient Mn (80.71\%) (Table 1). While using the BIK, a significant reduction in the sensitivity of the diagnosis was evident in situations with a higher coefficient of variation of the nutrient content in the reference population. This is attributed to the fact that the ranges originally proposed by Kenworthy (1961) for apple trees consider an average variability of $20 \%$ for each nutrient. This imparts a problem while dealing with micronutrients, as their leaf contents tend to have a variability greater than $20 \%$ (Rodrigues Filho et al., 2021). Thus, in situations of higher coefficient of variation, the reference values assume greater amplitudes and may prove inadequate, which can be optimized by using relative productivity classes (Lima Neto et al., 2020).

The optimum content for each nutrient (Table 1) was obtained from the linear models adjusted for the nutrient content in the cladodes as a function of the DRIS index and the average value $(100 \%)$ of the Balanced Indexes of Kenworthy in the normal class. For both methods, the values of the optimum content obtained were the same or very close, with no significant difference as per the t-test $(\mathrm{p}>$ 0.01). According to Urano et al. (2007), the average content in the high-yield population was in correspondence to the optimum content estimated by the relationship between the DRIS indexes and the leaf contents, validating the normal distribution of dual rations, with the assumption that the average is equal to the median.

A positive relationship was witnessed between the levels of all nutrients in the cladodes and the respective DRIS indexes and BIK (Table 2). DRIS indexes close to zero, below, and above zero indicated that the nutrient was in balance, deficiency, and excess, respectively (Beaufils, 1973). The statistical models reflecting the fit between the BIK and the nutrient content were all significant $(\mathrm{p}<0.01)$. In DRIS, positive and significant (at $1 \%$ ) relationships were revealed between the indexes and the concentrations of $\mathrm{N}, \mathrm{P}, \mathrm{S}, \mathrm{Mg}, \mathrm{Cu}, \mathrm{Fe}, \mathrm{Mn}, \mathrm{Zn}$, and $\mathrm{Na}$. The positive and significant (at 5\%) adjustment was noted for $\mathrm{K}$, whereas, for $\mathrm{Ca}$ and $\mathrm{B}$, the adjustments were non-significant ( $\mathrm{p}>$ 0.05 ). In the case of $\mathrm{N}, \mathrm{P}, \mathrm{S}, \mathrm{Cu}, \mathrm{Fe}, \mathrm{Mn}, \mathrm{Zn}$, and $\mathrm{Na}$, the higher determination coefficients $\left(\mathrm{R}^{2}>0.50\right)$ suggested the dependency of the DRIS index on the nutrient content itself in the cladode. On the contrary, for $\mathrm{K}, \mathrm{Ca}, \mathrm{Mg}$, and $\mathrm{B}$, a low relationship between these variables signified less dependence on the DRIS indexes of these nutrients with regards to their content in the cladode. In this case, there was a greater dependence on the concentrations of other nutrients in the formation of the DRIS index (Guindani; Anghinoni; Nachtigall, 2009).

In accordance with the research findings by Serra et al. (2012), micronutrients revealed a higher coefficient of determination $\left(\mathrm{R}^{2}\right)$ than macronutrients, except for $\mathrm{B}$, in the DRIS method. The relationships between the BIK and the concentration of nutrients documented an $\mathrm{R}^{2}$ of 1.00 , highlighting the smallest possible error without interfering with the significance of the mathematical model $(p<0.01)$.

The reference values of nutrients for the 'Gigante' cactus pear were derived on the basis of the relationship between the DRIS indexes, BIK, and the nutrient content in the cladodes of the high-yield population. These reference values were associated with the dry matter yields of 22.6 to $30.5 \mathrm{Mg} \mathrm{ha}^{-1}$ cycle $^{-1}$, in the DRIS method, and 20.7 to 32.3 $\mathrm{Mg} \mathrm{ha}^{-1}$ cycle $^{-1}$, in the BIK (Table 3).

For all classes and nutrients, the reference values obtained by the BIK method were broader than those obtained by the DRIS method. As reported by Serra et al. (2010), the amplitude of the reference values estimated by the DRIS method was also lower than other values documented in the literature. The wider the range, the greater is the propensity to get the nutrient content in the cladode of a sample within this range. On the other hand, this possibility decreases for a narrower range, enhancing the accuracy of the result (Guimarães et al., 2015). Dias et al. (2013) claimed that the estimated reference values would be lower in proportional to the standard deviation between the average nutritional levels of the high-yield population. In this sense, DRIS facilitates an increased advantage of identifying plots under nutritional imbalance as compared to BIK. The BIK method is thus less sensitive for the estimation of nutrients whose standards have a $\mathrm{CV}$ greater than $30 \%$, mainly for detecting deficiency situations because the intervals originally proposed by Kenworthy (1961) assume an average 20\% variability for each nutrient. In these cases, therefore, odd or even negative values have to be presumed as the reference values for the nutrient contents to be considered deficient, as occurred for $\mathrm{Fe}, \mathrm{Mn}$, and $\mathrm{Na}$. 
Table 1: Average, standard deviation (SD), and coefficient of variation (CV) for the concentration of nutrients and optimum content computed by the equations of the relationship between the DRIS index and the nutrient content in the cladode and by the BIK method in 'Gigante' cactus pear grown with an organic fertilizer in semiarid conditions in Bahia, for the high-yield population.

\begin{tabular}{crrrrr}
\hline \multirow{2}{*}{ Nutrient } & Mean & SD & & \multirow{2}{*}{ CV(\%) } & \multicolumn{2}{c}{ Optimal content } \\
\cline { 5 - 6 } $\mathrm{N}\left(\mathrm{g} \mathrm{kg}^{-1}\right)$ & 15.62 & 2.86 & 18.33 & 15.62 & \multicolumn{1}{c}{ BIK } \\
$\mathrm{P}\left(\mathrm{g} \mathrm{kg}^{-1}\right)$ & 1.46 & 0.67 & 45.71 & 1.46 & 1.46 \\
$\mathrm{~K}\left(\mathrm{~g} \mathrm{~kg}^{-1}\right)$ & 37.89 & 7.84 & 20.69 & 37.95 & 37.89 \\
$\mathrm{~S}\left(\mathrm{~g} \mathrm{~kg}^{-1}\right)$ & 1.57 & 0.50 & 32.04 & 1.57 & 1.57 \\
$\mathrm{Ca}\left(\mathrm{g} \mathrm{kg}^{-1}\right)$ & 28.03 & 4.83 & 17.22 & 27.99 & 28.03 \\
$\mathrm{Mg}\left(\mathrm{g} \mathrm{kg}^{-1}\right)$ & 11.88 & 3.01 & 25.30 & 11.88 & 11.88 \\
$\mathrm{~B}\left(\mathrm{mg} \mathrm{kg}^{-1}\right)$ & 27.50 & 5.18 & 18.84 & 27.47 & 27.50 \\
$\mathrm{Cu}\left(\mathrm{mg} \mathrm{kg}^{-1}\right)$ & 2.89 & 1.41 & 48.96 & 2.89 & 2.89 \\
$\mathrm{Fe}\left(\mathrm{mg} \mathrm{kg}^{-1}\right)$ & 93.89 & 54.51 & 58.06 & 94.16 & 93.89 \\
$\mathrm{Mn}\left(\mathrm{mg} \mathrm{kg}^{-1}\right)$ & 383.82 & 309.80 & 80.71 & 388.88 & 383.82 \\
$\mathrm{Zn}\left(\mathrm{mg} \mathrm{kg}^{-1}\right)$ & 46.18 & 19.46 & 42.14 & 46.21 & 46.18 \\
$\mathrm{Na}\left(\mathrm{mg} \mathrm{kg}^{-1}\right)$ & 43.01 & 21.95 & 51.04 & 42.96 & 43.01 \\
\hline
\end{tabular}

Source: Prepared by the authors.

Table 2: Statistical models adopted to adjust the nutrient content in the 'Gigante' cactus pear cladodes and the DRIS indexes and BIK, in high-yield plots.

\begin{tabular}{|c|c|c|c|c|}
\hline \multirow{2}{*}{ Nutrient } & \multicolumn{2}{|l|}{ DRIS } & \multicolumn{2}{|l|}{$\mathrm{BIK}$} \\
\hline & Equation & $\mathrm{R}^{2}$ & Equation & $\mathrm{R}^{2}$ \\
\hline $\mathrm{N}$ & $N=15.6188+2.7140 * * I_{N}$ & 0.54 & $N=-3.5045+0.1912^{* *} I_{N}$ & 1.00 \\
\hline$P$ & $P=1.4625+\left.0.8770 * *\right|_{P}$ & 0.77 & $P=-1.2314+\left.0.0269 * *\right|_{P}$ & 1.00 \\
\hline K & $\mathrm{K}=37.8906+6.7164 * \mathrm{I}_{\mathrm{K}}$ & 0.14 & $K=-9.8864+\left.0.4778 * *\right|_{K}$ & 1.00 \\
\hline$S$ & $S=1.5719+\left.0.7584 * *\right|_{S}$ & 0.58 & $S=-0.7412+0.0231 * * I_{S}$ & 1.00 \\
\hline $\mathrm{Ca}$ & $\mathrm{Ca}=28.0281+\left.2.1953^{\mathrm{ns}}\right|_{\mathrm{Ca}}$ & 0.04 & $\mathrm{Ca}=-5.8314+\left.0.3386^{* *}\right|_{\mathrm{Ca}}$ & 1.00 \\
\hline $\mathrm{Mg}$ & $\mathrm{Mg}=11.8844+2.8634^{* *} \mathrm{I}_{\mathrm{Mg}}$ & 0.43 & $\mathrm{Mg}=-4.0253+0.1591^{* *} \mathrm{I}_{\mathrm{Mg}}$ & 1.00 \\
\hline $\mathrm{B}$ & $B=27.4959+\left.2.9605^{\mathrm{ns}}\right|_{B}$ & 0.12 & $B=-6.3834+\left.0.3388 * *\right|_{B}$ & 1.00 \\
\hline $\mathrm{Cu}$ & $\mathrm{Cu}=2.8878+1.7937 * * \mathrm{I}_{\mathrm{Cu}}$ & 0.82 & $C u=-2.7699+\left.0.0566^{* *}\right|_{C u}$ & 1.00 \\
\hline $\mathrm{Fe}$ & $\mathrm{Fe}=93.8897+57.3785^{\left.* *\right|_{\mathrm{Fe}}}$ & 0.77 & $\mathrm{Fe}=-129.9822+\left.2.2387 * *\right|_{\mathrm{Fe}}$ & 1.00 \\
\hline $\mathrm{Mn}$ & $\mathrm{Mn}=383.8209+315.1045^{\star *} \mathrm{I}_{\mathrm{Mn}}$ & 0.83 & $\mathrm{Mn}=-1606.2740+19.9009 * * \mathrm{I}_{\mathrm{Mn}}$ & 1.00 \\
\hline $\mathrm{Zn}$ & $Z n=46.1844+\left.28.9165^{* *}\right|_{Z n}$ & 0.77 & $Z n=-33.6348+0.7982 * * I_{Z n}$ & 1.00 \\
\hline $\mathrm{Na}$ & $\mathrm{Na}=43.0141+22.8917 * * I_{\mathrm{Na}}$ & 0.78 & $\mathrm{Na}=-44.8333+\left.0.8785 * *\right|_{\mathrm{Na}}$ & 1.00 \\
\hline
\end{tabular}

** Significant at $1 \%$ by the t-test; * Significant at $5 \%$ by the t-test; ${ }^{\text {ns }}$ non-significant.

Source: Prepared by the authors.

The reference values obtained in this study deviated from those proposed by Alves et al. (2019a, b) by the Sufficiency Range technique. In general, for $\mathrm{P}$ and $\mathrm{S}$, the lower and upper limits of the classes, determined by the two methods, were close and in line with those proposed by these authors. A greater supply 
of these nutrients by organic matter, even with high $\mathrm{CV}$, $\mathrm{P}(45.71 \%)$ and $\mathrm{S}(32.04 \%)$, justifies this coincidence. Donato et al. (2016), in soil with $16.3 \mathrm{mg} \mathrm{dm}^{-3}$ of P found contents of $1.3 \mathrm{~g} \mathrm{~kg}^{-1}, 1.7 \mathrm{~g} \mathrm{~kg}^{-1}, 2.0 \mathrm{~g} \mathrm{~kg}^{-1}$, and $2.5 \mathrm{~g}$ $\mathrm{kg}^{-1}$ with the application of $0,30,60$, and $90 \mathrm{Mg} \mathrm{ha}^{-1}$ of manure, respectively. An increase in the remaining phosphorus from 41.8 to $45.0 \mathrm{mg} \mathrm{dm}^{-3}$ was also evident with 0 and $90 \mathrm{Mg} \mathrm{ha}^{-1}$ of bovine manure. This greater availability of $\mathrm{P}$ in the soil escalates the $\mathrm{P}$ content in the tissues of the cladodes beyond the sufficiency range, which can characterize luxury consumption. Simultaneously, $\mathrm{P}$ is a low export macronutrient in the dry matter by the cactus pear, $2.1 \mathrm{~kg} \mathrm{Mg}^{-1}$ (Donato et al., 2017b) and of low response to application (Dubeux Jr., 2010). Except for $P$ and $S$, the limits of the deficient, low class and the lower limit of the normal class obtained by the BIK method were lower than those reported by Alves et al. $(2019 \mathrm{a}, \mathrm{b})$.

Table 3: Reference values determined by DRIS and BIK methods in 'Gigante' cactus pear crop cultivated with organic fertilization in semiarid conditions of Bahia.

\begin{tabular}{|c|c|c|c|c|c|c|c|c|c|c|c|c|}
\hline \multirow{3}{*}{ Nutrient } & \multirow{3}{*}{ Method } & \multicolumn{11}{|c|}{ Reference Values } \\
\hline & & Deficient $^{1}$ & \multicolumn{3}{|c|}{ Low $^{1}$} & \multicolumn{3}{|c|}{ Normal } & \multicolumn{3}{|c|}{ High } & \multirow[t]{2}{*}{ Excessive } \\
\hline & & & & & & & $\mathrm{kg}$ & & & & & \\
\hline \multirow{2}{*}{$\mathrm{N}$} & DRIS & $<14.6$ & 14.6 & - & 15.1 & 15.1 & $\begin{array}{l}- \\
-1\end{array}$ & 16.1 & 16.1 & - & 16.7 & $\geq 16.7$ \\
\hline & $\mathrm{BIK}$ & $<6.1$ & 6.1 & - & 12.4 & 12.4 & - & 18.9 & 18.9 & - & 25.2 & $\geq 25.2$ \\
\hline \multirow{2}{*}{$P$} & DRIS & $<0.6$ & 0.6 & - & 1.0 & 1.0 & - & 1.9 & 1.9 & - & 2.4 & $\geq 2.4$ \\
\hline & $\mathrm{BIK}$ & $<0.1$ & 0.1 & - & 1.0 & 1.0 & - & 1.9 & 1.9 & - & 2.8 & $\geq 2.8$ \\
\hline \multirow{2}{*}{ K } & DRIS & $<37.3$ & 37.3 & - & 37.6 & 37.6 & - & 38.2 & 38.2 & - & 38.47 & $\geq 38.5$ \\
\hline & BIK & $<14.0$ & 14.0 & - & 29.8 & 29.8 & - & 46.0 & 46.0 & - & 61.8 & $\geq 61.8$ \\
\hline \multirow{2}{*}{$S$} & DRIS & $<0.9$ & 0.9 & - & 1.2 & 1.2 & - & 1.9 & 1.9 & - & 2.2 & $\geq 2.2$ \\
\hline & BIK & $<0.4$ & 0.4 & - & 1.2 & 1.2 & - & 2.0 & 2.0 & - & 2.7 & $\geq 2.7$ \\
\hline \multirow{2}{*}{$\mathrm{Ca}$} & DRIS & $<27.4$ & 27.4 & - & 27.7 & 27.7 & - & 28.3 & 28.3 & - & 28.6 & $\geq 28.6$ \\
\hline & $\mathrm{BIK}$ & $<11.1$ & 11.1 & - & 22.3 & 22.3 & - & 33.8 & 33.8 & - & 45.00 & $\geq 45.0$ \\
\hline \multirow{3}{*}{$\mathrm{Mg}$} & DRIS & $<11.0$ & 11.0 & - & 11.4 & 11.4 & - & 12.3 & 12.3 & - & 12.8 & $\geq 12.8$ \\
\hline & BIK & $<3.9$ & 3.9 & - & 9.2 & 9.2 & - & 14.6 & 14.6 & - & 19.8 & $\geq 19.8$ \\
\hline & & \multicolumn{11}{|c|}{$\mathrm{mg} \mathrm{kg}^{-1}$} \\
\hline \multirow{2}{*}{ B } & DRIS & $<26.7$ & 26.7 & - & 27.1 & 27.1 & - & 27.9 & 27.9 & - & 28.3 & $\geq 28.3$ \\
\hline & BIK & $<10.6$ & 10.6 & - & 21.7 & 21.7 & - & 33.3 & 33.3 & - & 44.4 & $\geq 44.4$ \\
\hline \multirow{2}{*}{$\mathrm{Cu}$} & DRIS & $<1.9$ & 1.9 & - & 2.4 & 2.4 & - & 3.4 & 3.4 & - & 3.8 & $\geq 3.8$ \\
\hline & BIK & $<0.1$ & 0.1 & - & 1.9 & 1.9 & - & 3.8 & 3.8 & - & 5.7 & $\geq 5.7$ \\
\hline \multirow{2}{*}{$\mathrm{Fe}$} & DRIS & $<92.8$ & 92.8 & - & 93.3 & 93.3 & - & 94.4 & 94.4 & - & 95.0 & $\geq 95.0$ \\
\hline & BIK & $<0.0$ & 0.0 & - & 55.8 & 55.8 & - & 131.9 & 131.9 & - & 205.8 & $\geq 205.8$ \\
\hline \multirow{2}{*}{$\mathrm{Mn}$} & DRIS & $<382.6$ & 382.6 & - & 383.2 & 383.2 & - & 384.4 & 384.4 & - & 385.0 & $\geq 385.0$ \\
\hline & BIK & $<0.0$ & 0.0 & - & 45.5 & 45.5 & - & 722.1 & 722.1 & - & 1378.9 & $\geq 1378.9$ \\
\hline \multirow{2}{*}{$\mathrm{Zn}$} & DRIS & $<45.4$ & 45.4 & - & 45.8 & 45.8 & - & 46.6 & 46.6 & - & 47.0 & $\geq 47.0$ \\
\hline & BIK & $<6.3$ & 6.3 & - & 32.6 & 32.6 & - & 59.8 & 59.8 & - & 86.1 & $\geq 86.1$ \\
\hline \multirow{2}{*}{$\mathrm{Na}$} & DRIS & $<41.9$ & 41.9 & - & 42.4 & 42.4 & - & 43.6 & 43.6 & - & 44.1 & $\geq 44.1$ \\
\hline & BIK & $<0.0$ & 0.0 & - & 28.1 & 28.1 & - & 57.9 & 57.9 & - & 86.9 & $\geq 86.9$ \\
\hline
\end{tabular}

1. Negative values have been replaced by zero. Source: Prepared by the authors. 
The sufficiency range proposed by Blanco-Macías et al. (2010) for $\mathrm{N}\left(8.4-20.3 \mathrm{~g} \mathrm{~kg}^{-1}\right)$ was wider than those derived by the DRIS method and narrower in relation to BIK. For P, the value obtained at the upper limit of the upper class, by the DRIS method, was in accordance with the lower limit of the range proposed by these authors, $2.4-4.2 \mathrm{~g} \mathrm{~kg}^{-1}$. Blanco-Macías et al. (2010) used soil with twice the organic matter and $\mathrm{K}$, two and a half times, 11 and five times more $\mathrm{P}, \mathrm{Ca}$, and $\mathrm{Mg}$, respectively. This rationalizes the higher class limits compared to those noted in this work for these nutrients. Alves et al. (2019a) justified the role of edaphoclimatic conditions responsible for these differences. However, the differences were also contributed by the methods adopted to determine the reference values.

The values obtained in this work were compared with the values of Mathematical Chances (ChM) established by Alves et al. (2019a, b). The largest ChM for $\mathrm{N}$ was found to comprise values between the normal and excessive range, by the DRIS method, and normal and high, by the BIK. The lower limit of ChM, for $\mathrm{P}\left(0.46 \mathrm{~g} \mathrm{~kg}^{-1}\right)$, was lower than the lower limits established for both methods. The ChM scans recorded for $\mathrm{K}, \mathrm{Ca}$, and $\mathrm{Mg}$ were wider in respect to the values established by the DRIS method and would all be located in the normal class, determined by the BIK, except for the lower limit determined for $\mathrm{Mg}$ by $\mathrm{ChM}$, which coincided with the low-class range. The narrower range for $\mathrm{S}$ was observed by $\mathrm{ChM}$ in relation to the two methods.

Regarding micronutrients, the lower limit of the $\mathrm{ChM}$ established for $\mathrm{B}, \mathrm{Cu}, \mathrm{Fe}, \mathrm{Mn}, \mathrm{Zn}$, and $\mathrm{Na}$ was lower than the limit of the deficient class of the respective nutrient, determined by the DRIS method. The sufficiency range of Alves et al. $(2019 \mathrm{a}, \mathrm{b})$ included the values of ChM for $\mathrm{B}$. The upper limit was in the deficient class for $\mathrm{Fe}$ and $\mathrm{Mn}$; in the normal class for $\mathrm{Cu}$ and $\mathrm{Na}$; in the high class for $\mathrm{B}$; whereas in the excessive class for $\mathrm{Zn}$. The lower limits of ChM when compared with the reference values found by the BIK method, all micronutrients, except Mn, were in the low class. The upper limits, for all micronutrients, were in the normal class.

The critical levels of nutrients in the cladodes were determined by Alves et al. (2019a, b) using the Critical Level method by the reduced normal distribution (NCRIz). NCRIz were below the limit of the deficient class, estimated by the DRIS method, except $\mathrm{P}$ and $\mathrm{S}$, which were in the low class. According to BIK, the NCRIz for $\mathrm{P}, \mathrm{S}, \mathrm{Cu}, \mathrm{Zn}$, and $\mathrm{Na}$ would be classified as low, the others in the normal class. However, the authors exploited the average dry matter productivity +0.5 standard deviations to separate the high and low-yield plots, a criterion different from this study. Diverse procedures can define the reference population and result in different norms, with varied efficacies (Serra et al., 2013).

The above findings thus suggested that the reference values, determined by the DRIS method, are more suitable for assessing the nutritional status of macronutrients because they have less amplitude in relation to the reference values estimated by the BIK and the Sufficiency Range proposed by Alves et al. (2019a, b). Furthermore, the lower and upper limits of the classes for $\mathrm{P}$ and S proposed by Alves et al. (2019a, b) were found to be similar to those documented by the two methods. For these macronutrients, NCRIz was included in the reference values determined by the DRIS. The NCRIz for N was also noted to be close to the lower limit of the deficient class, determined by the DRIS. Nachtigall and Dechen (2007) mentioned that, though similarity in performance to the sufficiency range criterion, the DRIS method manifested the added advantage of presenting NBI values, indicating the nutritional balance status of the plants and the efficiency in the nutritional diagnosis of the crop.

Likewise, compared to BIK, DRIS is more suitable for calculating the nutritional status of micronutrients. However, owing to the complexity of their dynamics in the soil-plant system, several factors affect the absorption and extraction of micronutrients (Abreu; Lopes; Santos, 2007). Moreover, the diagnosis for $\mathrm{Fe}, \mathrm{Mn}$, and $\mathrm{Na}$ may be compromised by the negative values for the limits of the deficient and lower class of the low class, evaluated by the BIK method. A correction factor was employed by Alves et al. (2019a, b) to minimize the range amplitude for nutrient cases with high variability, a very common case for micronutrients in tissues, with CVs above $20 \%$.

In a higher percentage, most of the nutrients were observed to be in the appropriate class of diagnosis (NL) (Table 4). The exception was Fe, which exhibited a deficiency in $37.5 \%$ of cases when evaluated by the fertilizer response class criterion. $\mathrm{pH}$, imbalance in the relationship with other micronutrients, such as $\mathrm{Mn}, \mathrm{Cu}$, and $\mathrm{Mo}$, excess of $\mathrm{P}$, clay content, soil source rock, and redox potential affect its availability in the soil. Interference in the ion-root contact (Abreu; Lopes; Santos, 2007), in the consequent absorption, and its content in tissues of the cactus pear cladodes can be contributed by these factors. Although data from the population of high-yield was used for the determination of the DRIS indexes and BIK, it verified that for all nutrients, there is a limitation due to lack and excess. Beaufils (1973) stated a greater effect of the deficiency of a nutrient on productivity than the excess. In this sense, there would be potential for response to fertilization in the plots where nutrients were considered as limited due to lack. 
Table 4: Frequency of classes of response to fertilization (\%) and relative frequency (\%) for nutrients $N, P, K, S, C a$, $\mathrm{Mg}, \mathrm{B}, \mathrm{Cu}, \mathrm{Fe}, \mathrm{Mn}, \mathrm{Zn}$, and $\mathrm{Na}$ in samples of cladodes of 'Gigante' cactus pear cultivated with organic fertilization in semiarid conditions, in the high-yield population.

\begin{tabular}{crrrrrr}
\hline \multirow{2}{*}{ Nutrient } & \multicolumn{3}{c}{ Classes of response to fertilization } & \multicolumn{4}{c}{ Relative Frequency } \\
\cline { 2 - 6 } & \multicolumn{1}{c}{ LF } & NL & LE & \multicolumn{1}{c}{ LF } & NL & LE \\
\hline N & 34.38 & 37.50 & 28.13 & 9.38 & 75.00 & 15.63 \\
P & 9.38 & 75.00 & 15.63 & 34.38 & 46.88 & 18.75 \\
K & 12.50 & 68.75 & 18.75 & 12.50 & 71.88 & 15.63 \\
S & 15.63 & 65.63 & 18.75 & 25.00 & 56.25 & 18.75 \\
Ca & 12.50 & 75.00 & 12.50 & 15.63 & 75.00 & 9.38 \\
Mg & 21.88 & 56.25 & 21.88 & 9.38 & 75.00 & 15.63 \\
B & 18.75 & 62.50 & 18.75 & 15.63 & 68.75 & 15.63 \\
Cu & 28.13 & 43.75 & 28.13 & 28.13 & 46.88 & 25.00 \\
Fe & 37.50 & 34.38 & 28.13 & 21.00 & 65.63 & 12.50 \\
Mn & 34.38 & 34.38 & 31.25 & 0.00 & 81.25 & 18.75 \\
Zn & 6.25 & 75.00 & 18.75 & 25.00 & 53.13 & 21.88 \\
$\mathrm{Na}$ & 21.88 & 40.63 & 37.50 & 28.13 & 53.13 & 18.75 \\
\hline
\end{tabular}

LF: limiting due to lack; NL: non-limiting; LE: limiting by excess, according to Silva et al. (2005). Source: Prepared by the authors.

Regarding the classes of response to fertilization, limitations were not observed in the case of $\mathrm{P}, \mathrm{Ca}$, and $\mathrm{Zn}$ in $75 \%$ of the experimental plots. The relative frequency obtained through BIK revealed that the nutrients $\mathrm{Mn}(81.25 \%)$ and $\mathrm{N}, \mathrm{Ca}$, and $\mathrm{Mg}$, with $75 \%$ each, did not limit productivity. Thus according to both these methods, $\mathrm{Ca}$ was one of the nutrients that did not present a limitation to productivity. Donato et al. (2014a) claimed a positive effect of the doses of bovine manure on the phosphorus content in the tissues of the cladodes, regardless of the spacing. Greater availability and mobility of $\mathrm{P}$ in the soil were facilitated by organic fertilization as compared to chemical fertilizers. Although regardless of the source used, the absorption of $\mathrm{P}$ by the plant was favored by the higher doses of the fertilizers (Ledo et al., 2021). In this work, the extraction of $\mathrm{P}$ was $1.4 \mathrm{~kg} \mathrm{Mg}^{-1}$. Insufficiency of Ca supply by organic fertilization resulted in maintenance of cactus pear yield by soil buffer capacity. One of the most exported elements by cactus pear is $\mathrm{Ca}$, based on the production cycle and the source used (Ledo et al., 2021).

Similarly, the most limiting elements included $\mathrm{Fe}$ (37.50\%), N (34.38\%), and Mn (34.38\%), owing to the lack of response to fertilization. The relative frequency revealed P deficiency (34.38\%) was the most limiting, followed by $\mathrm{Cu}$ and $\mathrm{Na}$, whose frequencies were $28.13 \%$. Iron extraction/export was independent of spacing and organic fertilization. On the other hand, the concentration and availability in the soil influenced the extraction of $\mathrm{N}$ (Silva et al., 2016), which in this work was $15.7 \mathrm{~kg} \mathrm{Mg}^{-1}$. Donato et al. (2017a) observed that $\mathrm{N}$ extraction/export values ranged from 8.8 to $17.6 \mathrm{~kg} \mathrm{Mg}^{-1}$ in dry matter, in response to escalating doses of bovine manure applied to the soil from 0 to $90 \mathrm{Mg} \mathrm{ha}^{-1}$ year $^{-1}$. The fertilization and spacing factors also affected the extraction of $\mathrm{Mn}$, which was less in double rows (Silva et al., 2016).

The high-yield population was formed, in $81.25 \%$, by plots receiving the highest doses of bovine manure, 60 and $90 \mathrm{Mg} \mathrm{ha}^{-1}$ year $^{-1}$. An increase in $\mathrm{pH}$ is witnessed with the addition of bovine manure to acidic soils because of the consumption of $\mathrm{H}^{+}$of the soil solution by organic acids, decreasing the availability of Mn. Donato et al. (2016) justified the lower levels of $\mathrm{Mn}$ in the 'Gigante' cactus pear cladodes by increasing the $\mathrm{pH}$ from 5.4 (before planting) to $6.0,6.1$, and 6.2 with the supplementation of 30,60 , and $90 \mathrm{Mg} \mathrm{ha}^{-1}$ year $^{-1}$ of manure, respectively.

The nutrients mostly recognized as limiting by excess were $\mathrm{Na}(37.50 \%)$ and $\mathrm{Mn}(31.25 \%)$, according to the class of response to fertilization, and $\mathrm{Cu}(25.00 \%)$ and $\mathrm{Zn}(21.88 \%)$ by the relative frequency. Although not essential for all species, Broadley et al. (2012) stated that for plants with crassulacean acid metabolism (CAM), for example, the species of Opuntia, $\mathrm{Na}$ is a micronutrient as it is essential for the regeneration of phosphoenolpyruvate, 
a substrate of the first carboxylation in this pathway, and its deficiency induces chlorosis and necrosis, as well as failure in the formation of flowers.

Divergence has been reported between the methods, in the nutritional diagnosis, with variations in the hierarchical order of the limitation, due to lack or excess, and of the nutrients not limiting the productivity. This is attributed to the diverse assumptions of the methods; the DRIS method evaluates equilibrium, while the BIK method estimates nutritional balance better. In this case, the variation in the doses of bovine manure resulted for all nutrients in different classes of response to fertilization and relative frequency of nutrient content in the cladodes.

It is noteworthy that the percentage deviation of the concentration of a given nutrient from the norm estimates the degree of balance, taking into account the coefficients of variation observed for each nutrient in the population from which the norms were obtained. However, the bivariate ratios between nutrients evaluate the degree of equilibrium, considering the largest ratio among the variances of high-yield and low-yield populations. The plant may present an adequate amount of the nutrient with the simultaneous absence of nutritional equilibrium. Henceforth, to avoid such false diagnoses, the nutritional assessment must consider the degrees of balance and equilibrium between the nutrients.

Although Souza et al. (2013) claimed a significant relationship between NBIa and productivity, indicating that production was associated with nutritional status, it is possible to find crops with low yield, despite having adequate NBI. This fact may suggest that the limitation in productivity may not be nutritional and assume values greater than nutritional limitation (Rodrigues Filho; Neves; Donato, 2021). The present study failed to portray such a relationship between NBI, NBIa, and productivity, corroborating Santos and Rozane (2017) in their work with atemoya. The size of the cladodes, influencing productivity, was determined by genotypic factors and, to a lesser extent, by environmental and management factors such as the disposition of planting and soil fertility (Nobel, 2001). According to Donato et al. (2014a) and Matos et al. (2020), the use of radiation and the nutritional status of the plant can be improved by alteration in crop management, such as a combination of spacing and fertilizer doses, with a subsequent enhancement in photosynthetic rates, growth, productivity, and nutritional composition of the different genotypes.

\section{CONCLUSIONS}

Variation in the reference values drafted by the DRIS and BIK methods from each other and the literature was noted for all nutrients. No association was observed between the productivity of the 'Gigante' cactus pear with the nutritional balance index, determined by the DRIS method. The present study thus highlighted the efficacy of the DRIS and BIK methods in identifying the limiting nutrients for 'Gigante' cactus pear, with differences in the hierarchical order of the limitation, due to lack or excess, and the non-limiting nutrients to productivity.

\section{AUTHOR CONTRIBUTION}

Conceptual idea: Teixeira, M. B.; Donato, S. L. R.; Silva, J. A.; Donato, P. E. R.; Methodology design: Teixeira, M. B.; Donato, S. L. R.; Silva, J. A.; Donato, P. E. R.; Data collection: Donato, P. E. R.; Silva, J. A.; Donato, S. L. R.; Teixeira, M. B.; Data analysis and interpretation: Teixeira, M. B.; Donato, S. L. R.; Silva, J. A.; Donato, P. E. R.; and Writing and editing: Teixeira, M. B.; Donato, S. L. R.; Silva, J. A.; Donato, P. E. R.

\section{REFERENCES}

ABREU, C. A.; LOPES, A. S.; SANTOS, G. Micronutrientes. In: NOVAIS, R. F. et al. (Ed.). Fertilidade do solo. Viçosa: Sociedade Brasileira de Ciência do Solo, p.645-733, 2007.

ALMEIDA, R. F. Palma forrageira na alimentação de ovinos e caprinos no Semiárido brasileiro. Revista Verde de Agroecologia e Desenvolvimento Sustentável, 7(4):814, 2012.

ALVAREZ, V.; V. H.; LEITE, R. A. Fundamentos estatísticos das fórmulas usadas para cálculos dos índices DRIS. 24(1):2025, 1999. (Boletim informativo - SBCS).

ALVES, J. F. T. et al. Establishment of sufficiency ranges to determine the nutritional status of 'Gigante' cactus pear macronutrients. Journal of Agricultural Science, 11(18):213221, 2019a.

ALVES, J. F. T. et al. Establishment of sufficiency ranges to determine the nutritional Status of 'Gigante' cactus pear - micronutrients. Journal of Agricultural Science, 11(18):222229, $2019 b$.

ATTAR, S. K.; JOOLKA, N. K. Diagnosis and recommendation integrated system (DRIS) norms for apple cv. Starking Delicious. The Bioscan, 10(3):1287-1294, 2015. 
BARROS, J. L. et al. Palma forrageira 'Gigante' cultivada com adubação orgânica. Revista Agrotecnologia, 7(1):53-65, 2016.

BEAUFILS, E. R. Diagnosis and recommendation integrated system (DRIS): A general scheme for experimentation and calibration based on principles developed from research in plant nutrition. Pietermararitzburg: University of Natal, 1973. 132p.

BLANCO-MACÍAS, F. et al. Comparison between CND norms and boundary-line approach nutrient standards: Opuntia ficus-indica L. case. Revista Chapingo Serie Horticultura, 15(2):217-223, 2009.

BLANCO-MACÍAS, F. et al. Nutritional reference values for Opuntia ficus-indica determined by means of the boundaryline approach. Journal of Plant Nutrition and Soil Science, 173(6):927-934, 2010.

BROADLEY, M. et al. Beneficial elements. 3. rd ed. In: MARSCHNER, P. (Ed.). Marschner's mineral nutrition of higher plants. Amsterdam, Netherlands: Elsevier, p. 249269, 2012.

DIAS, J. R. M. et al. Níveis críticos e faixas de suficiência nutricional em laranjeira-pêra na Amazônia Central obtidas pelo método DRIS. Acta Amazonica, 43(3):239-246, 2013.

DONATO, P. E. R. et al. Extraction/exportation of macronutrients by cladodes of 'Gigante' cactus pear under different spacing and organic fertilizer. Revista Brasileira de Engenharia Agrícola e Ambiental, 21(4):238-243, 2017a.

DONATO, P. E. R. et al. Morfometria e rendimento da palma forrageira 'Gigante' sob diferentes espaçamentos e doses de adubação orgânica. Revista Brasileira de Ciências Agrárias, 9(1):151-158, 2014a.

DONATO, P. E. R. et al. Nutrition and yield of 'Gigante' cactus pear cultivated with different spacings and organic fertilizer. Revista Brasileira de Engenharia Agrícola e Ambiental, 20(12):1083-1088, 2016.

DONATO, P. E. R. et al. Valor nutritivo da palma forrageira 'Gigante' cultivada sob diferentes espaçamentos e doses de esterco bovino. Revista Caatinga, 27(1):163-172, 2014b.

DONATO, S. L. R. et al. Diagnóstico nutricional e recomendação de adubação para a palma forrageira 'Gigante'. Informe Agropecuário, 38(296):46-58, 2017b.

DUBEUXJÚNIOR, J. C. B. et al. Adubação mineral no crescimento e composição mineral da palma forrageira Clone IPA-20. Revista Brasileira de Ciências Agrárias, 5(1):129-135, 2010.
GUIMARÃES, F. C. N. et al. Nutrients optimum range (NOR) based on DRIS method to assess the nutritional status of the first ratoon sugarcane. Australian Journal of Crop Science, 9(7):638-645, 2015.

GUINDANI, R. H. P.; ANGHINONI, I.; NACHTIGALL, G. R. DRIS na avaliação do estado nutricional do arroz irrigado por inundação. Revista Brasileira de Ciência do Solo, 33(1): 109-118, 2009.

INSTITUTO BRASILEIRO DE GEOGRAFIA E ESTATÍSTICA - IBGE. Censo Agropecuário 2017: Resultados definitivos. Available in: <https://censos.ibge.gov.br/agro/2017/resultadoscenso-agro-2017.html>. Access in: January, 20, 2021.

JONES, C. A. Proposed modifications of the diagnosis and recommendation integrated system (DRIS) for interpreting plant analyses. Communications in Soil Science and Plant Analysis, 12(8):785-794, 1981

KENWORTHY, A. L. Interpreting the balance of nutrientelements in leaves of fruit trees. In: REUTHER, W. Plant analysis and fertilizers problems. Washington: American Institute of Biological Science, p.28-23, 1961.

KENWORTHY, A. L. Leaf analysis as an aid in fertilizing orchard. In: WALSH, L. O.; BEATON, J. D. Soil testing and plant analysis. Madison: Soil Science Society of America, p.381392, 1973.

LEDO, A. A. et al. Nutritional balance and recovery rate of macronutrients by 'Gigante' cactus pear under different fertilizations. Revista Brasileira de Engenharia Agrícola e Ambiental, 25(2):82-89, 2021.

LIMA NETO, A. J. et al. Establishment of critical nutrient levels in soil and plant for eucalyptus. Revista Brasileira de Ciência do Solo, 44:e0190150, 2020.

MATOS, L. V. et al. Structural characteristics and yield of 'Gigante' cactus pear in agroecosystems in the semi-arid region of Bahia, Brazil. Revista Caatinga, 33(4):1111-1123, 2020.

NACHTIGALL, G. R.; DECHEN, A. R. DRIS norms evaluating the nutritional state of apple tree. Scientia Agricola, 64(3):282287, 2007.

NOBEL, P. S. Biologia ambiental. In: BARBERA, G. et al. (Eds.). Agroecologia, cultivo e uso da palma forrageira. João Pessoa: SEBRAE-PB/FAO, p.36-48, 2001,

RODRIGUES FILHO, V. A. et al. Universality of kenworthy and DRIS norms for RPFta and Cavendish bananas grown in two environments. Revista Brasileira de Ciência do Solo, 45:e0200120, 2021. 
RODRIGUES FILHO, V. A.; NEVES. J. C. L.; DONATO, S. L. R. Model to estimate nutritional and non-nutritional limitations of 'RPFta-Anã' banana crops grown in different environments. Revista Caatinga, 34(1):58-67, 2021.

SANTOS, E. M. H.; ROZANE, D. E. DRIS standard and normal ranges of foliar nutrients for the culture of 'Thompson' atemoya. Ciência Rural, 47(4):e20160613, 2017.

SANTOS, H. G. et al. Sistema Brasileiro de Classificação de Solos. 5. ed. Brasília, DF: Embrapa, 2018. 356p.

SERRA, A. P. Beaufils ranges to assess the cotton nutrient status in the Southern region of Mato Grosso. Revista Brasileira de Ciência do Solo, 36(1):171-181, 2012.

SERRA, A. P. et al. Desenvolvimento de normas DRIS e CND e avaliação do estado nutricional da cultura do algodoeiro. Revista Brasileira de Ciência do Solo, 34(1):97-104, 2010.

SERRA, A. P. et al. Estabelecimento de normas DRIS para o algodoeiro com diferentes critérios de seleção da população de referência. Pesquisa Agropecuária Brasileira, 48(11):1472-1480, 2013.

SILVA, G. G. C. et al. Avaliação da universalidade das normas DRIS, M-DRIS, e CND. Revista Brasileira de Ciência do Solo, 29(5):755-761, 2005.
SILVA, J. A. et al. Yield and vegetative growth of cactus pear at diferent spacings and under chemical fertilizations. Revista Brasileira de Engenharia Agrícola e Ambiental, 20(6):564-569, 2016.

SOIL SURVEY STAFF. Keys to soil taxonomy. 12th ed. Washington, DC: United States Department of Agriculture, Natural Resources Conservation Service, 2014. 372p.

SOUZA, H. A. et al. Normas preliminares DRIS e faixas de suficiência para goiabeira 'Paluma'. Revista Brasileira de Fruticultura, 35(1):282-291, 2013.

TEIXEIRA, M. B. et al. Establishment of DRIS norms for cactus pear grown under organic fertilization in semiarid conditions. Revista Caatinga, 32(4):952-959, 2019.

URANO, E. O. M. et al. Determinação de teores ótimos de nutrientes em soja pelos métodos chance matemática, sistema integrado de diagnose e recomendação e diagnose da composição nutricional. Revista Brasileira de Ciência do Solo, 31(1):63-72, 2007.

WADT, P. G. S. Relationships between soil class and nutritional status of coffee plantations. Revista Brasileira de Ciência do Solo, 29(2):227-234, 2005. 